\title{
Teaching Assistant Unionization: Origins and Implications ${ }^{1}$
}

\author{
ROBERT ROGOW* and DANIEL R. BIRCH**
}

\begin{abstract}
Teaching assistants are represented by unions in the majority of large universities in Ontario and British Columbia (and in one smaller Saskatchewan university). Both traditional economic motivation and social/psychological/political factors appear to have contributed to unionization. The unionized universities tend to be in urban settings, to have large graduate student enrolments and to have faced greater budgetary concerns at the time of unionization. Graduate students in those first unionized had lower incomes than others and a higher proportion enrolled in the humanities and social sciences and the discrepancy was greater between the income of students in these fields and that of students in other fields.

The refusal of labour relations boards in Canada to allow the "student" relationship to invalidate an "employee" relationship contrasts with decisions of the (U.S.) National Labour Relations Board. This and the fact that Canadian public policy is generally more supportive of public sector unionization and more protective of unions during the period of organizing and negotiating a first agreement, perhaps account for the greater extent of T.A. unionization in Canada than in the U.S.

Although as short-term, part-time employees, T.A. 's would seem to be unlikely candidates for unionization, T.A. bargaining is now an accepted institutional reality with collective agreement achievements to point to and dues income to draw on. Future budgetary, program and priority changes are likely to generate graduate student anxiety and trigger further T.A. unionization.
\end{abstract}

\section{RÉSUMÉ}

Les maitres-assistants de neuf universités canadiennes se sont syndiqués de 1974 $\hat{a}$ 1980. Les neuf disposaient d'un plus grand effectif estudientin post-gradué, et devaient faire face a des budgets plus serrés, que ceux chez leurs semblables non-

* Faculty of Business Administration, Simon Fraser University

** Faculty of Education, University of British Columbia 
syndiqués. Les étudiants post-gradués des neuf touchaient des revenus faibles avant l'avènement des syndicats - et au plus grand nombre étaient inscrits dans les sciences humaines ou sociales.

La politique de la société canadienne diffère de celle des $E$.-U., où se trouvent peu de syndicats des maitres-assistants. L'une des divergences se fait remarquer: la volonté chez les Commissions provinciales canadiennes des Relations Industriel. les d'accorder aux maitres-assistants le statut d' "employé," et ainsi de leur garantir la certification.

Between 1974 and 1980 unions representing graduate teaching assistants (T.A.s) on nine Canadian university campuses were certified by Canadian labour relations boards and collective bargaining relationships were established. "Certification" refers to the designation of a union as the governmentally recognized bargaining representative of a group of employees. This recognition bears with it a legal obligation on the employer to bargain with the union in good faith. The Toronto T.A. union achieved certification in 1974, followed by York's two units in 1975. A gap in certifications followed until 1978, when Regina, Lakehead, and Simon Fraser were certified. In 1979 McMaster and Carleton, and in 1980 British Columbia and OISE were certified.

In attempting to explain this development we note in the first section of this paper the circumstances differentiating campuses where it occurred from otherwise comparable Canadian universities and, in the second section, some more universal factors which also contributed. We then discuss the potential implications for the university administrator and conclude with a prediction about the expansion of T.A. bargaining. ${ }^{2}$

No formal theory of unionization is presented here, largely because of the relatively amorphous and inconsistent state of research and conceptualizing in this area (Fiorito \& Greer, 1982, p. 19). Informally, some combination of traditional trade unionist economic motivations (e.g., increasing incomes or job security) and social/psychological/political motivations (e.g., increasing participation, decreasing discrimination) was initially surmised to be at work. Information believed relevant to such motivations was sought out, and is summarized in the first two sections.

\section{DISTINGUISHING FEATURES OF UNIVERSITIES WHERE TEACHING ASSISTANTS UNIONIZED}

Within two groups, university characteristics and graduate student characteristics, the differentiating circumstances are presented in descending order of apparent influence on the certification process.

\section{University Characteristics}

Location. "Location" may be a surrogate for quite a number of other factors. For example, large city size could be a surrogate for a relatively large pool of 
non-student or part-time student competitors for T.A. jobs; for a "commuter campus" social milieu; or for a large pool of politically sympathetic allies and resource persons in the labour movement, in other "movements", and in the legal profession.

Urbanism may be a factor. Toronto was the location of the two initial sites of T.A. unionization. None of the T.A. collective bargaining campuses is in a "university town" or in a generally rural and/or socially conservative setting. Where it is in a smaller community it appears to be a strong union setting.

Another locational circumstance is the concentration of unionized campuses in Ontario. That seven of the ten units (six of nine universities) are in Ontario is explainable only in part by that province's large size.

Budgetary concerns. Fears of university budgetary stringency may provide part of the explanation for support of collective bargaining in Ontario in the mid and late 1970s. Provincial government operating grants increased at a slower rate in Ontario between $1974-75$ and $1980-81$ than in any other province. The differences are large: Ontario's increase was $70 \%$, versus the $118 \%$ weighted average of the other nine provinces. In operating grants per full-time student, Ontario fell from fifth place in 1974-75 to tenth place in 180-81 (COU, Brief, 1981, pp. 8-11). A perception of T.A.s as the residual claimants, as the sole "variable cost" element in an increasingly unionized university community, accentuated these concerns.

Large size. It may be significant that unionization began at University of Toronto, Canada's largest in number of graduate students. On the eve of certification (1973-74) Toronto had 4,305 full-time graduate students. This was $32 \%$ of all graduate students in Ontario and $164 \%$ more than the second-ranking Ontario university (COU, 1973-74, Table 1). Toronto also has one of the country's highest ratios of graduate students to total student enrolment.

Size of graduate student enrolment appears relevant, at least in a threshold sense. Four of the eight larger graduate-enrolement Ontario universities were unionized, but only one of the seven smaller-enrolment ones was. The two B.C. universities with larger graduate enrolments were unionized but the one with smaller graduate enrolment was not.

Size may contribute to unionization by increasing the likelihood of student alienation and of variability in employment conditions. It may make a bargaining unit more viable by increasing the resource potential. Large numbers contribute to bureaucratization and a weakening of personal ties between graduate student and faculty member. As for variability in employment conditions, Toronto was reported to have had more than 400 different compensation/duties ratios among its potential bargaining unit members on the eve of unionization. Perceived variability was an issue in all certification drives. Even at Simon Fraser, probably the most consistent in compensation/duties ratio, perceived inequities formed a major element in the Union's campaign.

A certain minimum size may make a local more viable as a relatively independent unit. The mean size of the ten Canadian bargaining units is 700 , many times 
the mean size of newly certified units in Canadian society generally. Dues generating potential, fraternal support and legal advice may all be more available to a larger unit.

Administrative decentralization. All Canadian universities are, in regard to their academic activities, decentralized organizations. Faculties, departments, and individual instructors have (in the area of determining the work that they will do and how they will do it) much more autonomy than is usually true of their counterpart managers and professionals in non-university organizations of similar size and complexity. This decentralization led to wide variation in employment conditions, which in turn led to the strong sense of inequity that appears to have been a major contributor to the support for unionization. Toronto, the first to unionize, decentralized T.A. conditions much more than most. We have no evidence, however, that the degree of decentralization in the other eight unionized universities exceeded that of comparable institutions.

\section{Graduate Student Characteristics}

We generated a list of characteristics we considered to be potentially favourable to unionization. Because size of graduate student population appeared to be important, at least in a threshold sense, we limited our comparisons to the large uniyersities. Of eight large Ontario universities teaching assistants have unionized at four (Toronto, York, Carleton and McMaster) and not at the others (Western Ontario, Waterloo, Queen's and Ottawa). With the exception of Toronto (by far the largest), full-time graduate student populations at the other seven in 1979-80 ranged from 900 to 1800 .

The question we posed was whether the unionizing universities, in the immediate pre-certification period, displayed the following pro-unionization characteristics to a greater degree than did the non-unionizing universities: higher proportion of graduate students in the humanities and social sciences, higher proportion of part-time graduate students, lower graduate student incomes, wider gap between the income of humanities and social science graduate students and that of others, greater dependence on T.A. income, and lower proportion of doctoral students.

The 1973-74 academic year was used to compare Toronto (certified in 1974) and York (certified in 1975) against the other six large universities. The 1978-79 academic year was used to compare Carleton and McMaster (both certified in 1979) against the four remaining non-unionized large universities.

Humanities and social sciences. Such students tend to have value orientations more sympathetic to unionization as part of their being more politically "aware/ militant/anti-establishment" than other graduate students. This portrayal is supported by the university folk culture, the authors' observation and some research. For example, Lipset (1979, pp. 75-76) points to the sharp differences in political culture between the social science and humanities disciplines on the one hand and the natural sciences and professional disciplines on the other. The 
University of Michigan first-agreement strike "was most effective in a limited number of liberal arts departments" (Forsyth, 1976, p. 311). In the 1969 Wisconsin union recognition vote (in which the union won $77 \%$ of the vote) "the only departments with a significant number of T.A.s which rejected the TAA were Business, Chemistry, Chemical Engineering, and Law" (Feinsinger \& Roe, 1971, p. 250). Quarter (1972, pp. 64-67), in a study of Canadian student activism characterizes arts students in a similar fashion.

Three of the four unionized universities had higher proportions of humanities and social science graduate students than did the median large non-unionized university (Toronto $68 \%$ and York $84 \%$ versus a non-union median of $65 \%$; Carleton $72 \%$ and McMaster $55 \%$ versus a non-union median of $68 \%$ ). The differences, however, are neither dramatic nor consistent.

Part-time students. Part-timers may be better unionization material because they are less affluent, less socialized or coopted into their departmental (i.e. faculty's and administrators') identity and value systems; and their off-campus connections, family backgrounds and work experience are more pro-unionization.

All four unionized universities had higher proportions of part-time graduate students than did the median large non-unionized university (Toronto $43 \%$ and York $49 \%$ versus a non-union median of $34 \%$; Carleton $45 \%$ and McMaster $38 \%$ versus a non-union median of $34 \%$ ).

Lower graduate student incomes. If economic factors were a major cause of unionization we might expect to find more pressure to unionize among those T.A.s receiving the lowest rates of remuneration. In fact, the two large universities which unionized first showed lower median graduate student incomes on the eve of unionization than did comparable institutions (Toronto $\$ 1800$ and York $\$ 2100$ versus a non-union median of $\$ 2500$ ). Graduate student stipends had been "frozen" in Ontario, first at $\$ 1800$ then at $\$ 2400$. In March 1974 the limit was raised to $\$ 3000$ but budgetary constraints at Toronto and York prevented those institutions from increasing stipends to the extent others did. Thus it appears that this factor was important in the initial unionization campaigns. However, institutions which unionized later did not fit that pattern. Carleton's $\$ 3200$ exceeded the non-union median of $\$ 2900$ and McMaster at $\$ 6000$ was a striking exception, which hints at the limitations of simple economic motivation as the major explanation of student interest in unionization.

Lower incomes in humanities and social sciences. On virtually all campuses the income level of graduate students in the humanities and social sciences is lower than that of students in other fields. If economic motivations were an important contributor to the desire to unionize, we would expect the discrepancy to be greater at the unionized universities. This was the case for the first two unionized campuses, Toronto and York. The average graduate student in the humanities and social sciences at Toronto had only $31 \%$ as much income as the average graduate student in another field. For York the figure was $57 \%$ versus a non-union median of $59 \%$. On this as on the previous factor the hypothesized 
relationship did not hold true for Carleton or McMaster, where teaching assistants unionized later.

Dependence on T.A. income. Once again if economic motivation is an important contributor to T.A. unionization, greater dependence on T.A. income (measured as the ratio of T.A. income to all university-transmitted income) might be expected to encourage unionization. This was clearly not the case in the first two universities unionized. T.A. income accounted for only $29 \%$ and $34 \%$ of graduate student income at Toronto and York respectively versus a nonunion median of $41 \%$. Carleton and McMaster, however, had ratios in the expected direction ( $56 \%$ and $50 \%$ versus a non-union median of $40 \%$ ).

Proportion of doctoral students. Doctoral candidates, with higher incomes, higher status, and closer ties to department and faculty mentors, might be expected to be less union-prone than other graduate students. Contrary to expectations, three of the four (including the first two) unionized universities had higher proportions of doctoral students than did comparable non-unionized universities (Toronto $54 \%$ and York $42 \%$ versus a non-union median of $41 \%$; McMaster $49 \%$ versus a non-union median of $41 \%$ ). Carleton was the only one of the four with a proportion of doctoral students $(26 \%)$ well below the non-union median. It may be that doctoral students, having been graduate students longer and holding proportionately more appointments as T.A.s, are more socialized to graduate student norms and feel more keenly any grievances, real or imagined. If so, a student body with a higher proportion of doctoral students would be more rather than less likely to unionize.

\section{FEATURES CONTRIBUTING TO UNIONIZATION ALTHOUGH COMMON TO CANADIAN UNIVERSITIES}

Several characteristics of universities in general and of their graduate student populations in particular appear to have contributed to the trend toward T.A. certification. However, these characteristics distinguishing the unionized universities from others were not the only pro-unionization factors at work. They were supplemented by several general Canadian environmental features, the latter being necessary but not sufficient conditions for unionization.

In descending order of apparent influence on the certification process are some characteristics of Canadian public policy, student leadership characteristics and faculty bargaining characteristics, none of which differentiates the unionized universities from the non-unionized.

\section{Characteristics of Canadian Public Policy}

We have concluded that the public policy context is a major - probably the major - factor in the emergence of T.A. bargaining. Favourable labour legislation and sympathetic interpretation thereof by the labour relations boards of Ontario, British Columbia, and Saskatchewan appear to have contributed significantly to the success of T.A. unionization. This treatment has been more favourable, and more consistently favourable, to unionization than has U.S. treatment. 
Only "employees" as defined in the labour relations statute receive its protection. Other people (for example, managerial employees or independent contractors) are denied the law's compulsion on the employer to bargain, its restriction on employer anti-unionization tactics, and its legal protection of concerted action. Generally, groups not considered employees have been unsuccessful in achieving a collective bargaining relationship.

There are a number of possible bases on which a labour relations board might have declared T.A.s to be non-employees. Compared to most people meeting the employee definition their employment is short-term, casual, part-time and high-turnover - and each of these characteristics might have been (but was not) interpreted as weakening employee status. In addition, the bargaining units requested might have been found inappropriate for bargaining because of insufficient "community of interest" among their members or because their members might more appropriately be assignable to alternative units (faculty or clerical and technical).

These are minor bases of possible exclusion, however, compared to the question of whether student status overwhelms and negates employee status at the student's educational institution.

Students" "employee" status. In a literal sense the question, "Are student T.A.s employees?", is a trivial one and one easily answered. ${ }^{3}$ Most graduate student employees of the universities they attend meet the normal tests of employee status (work that benefits the employer, direction and disicipline by the employer, payroll office treatment, income tax and unemployment insurance treatment, etc.). The more important question that labour boards had to resolve was whether employee status (and the collective bargaining relationship made possible by that status) was consistent with student status (and the university's related mission, governance responsibilities, and authority systems).

If sufficient incompatibility were found between the two statuses the labour boards would have to use the discretion granted them by statute to determine which of the two would have to give way. Such decisions would have to balance the collective bargaining rights of the T.A.s (and the possible gains in terms and conditions achievable through bargaining) against the possible damage such bargaining might cause to the quality of graduate and undergraduate education and to faculty or administrator authority over instruction. Since for most T.A.S employee status was secondary to and contingent upon student status, labour board expectations of serious damage to the mission of the employing university would probably have led to a denial of collective bargaining rights through the legal fiction that student T.A.s are not employees, the predominant U.S. position (Rogow \& Birch, 1983, pp. 52.63).

Canadian labour relations boards in contrast to this stance have consistently believed that student status - and student/faculty ręlations that might overlap with employee/employer relations were not a bar to employee status under the statutes. The first two T.A. certification decisions in Canada (in 1974, concerning the University of Toronto) found student units appropriate without any explicit reference to employee status. This is a bit surprising, especially since one of the 
decisions in its unit description referred to bargaining unit work as done "in conjunction with their graduate studies" (Ontario Labour Relations Board, Victoria University decision, 1974).

In 1975 the OLRB, in a York University decision, addressed employee status directly. T.A.s were held to be employees for two reasons. First, the work performed

forms a necessary and essential element in the teaching and the administration of the academic courses conducted by the respondent university. (Canadian Labour Relations Boards Reports, 1976, 1, p. 230)

That is, the work was "of direct and immediate benefit to the employer", a conventional legal criterion of employee status. Second, the work performed

generally forms no specific part of the graduate student's own academic program [and] there was no attempt to integrate the teaching functions performed. . . with the individual's graduate program... . (ibid, pp. 229-230)

The same decision held that, unlike the above category of "Student Teaching Assistants", people classified as "Student Graduate Assistants" at York were not employees, for two reasons. First, the work involved was often of a somewhat spurious or trivial characer,

a "make work" scheme primarily designed to qualify these students for Government-support monies in an effort to provide them with some financial assistance while pursuing their particular post-graduate course of studies. (ibid, p. 230)

Second, where work was performed it was not usually of direct benefit to the university. For example, in contrast to T.A. positions, G.A. positions for which no student was available were left vacant. ${ }^{4}$ This second criterion also appeared to imply that research assistants and "gofers" for faculty were not employees at least, not employees of the university.

The York decision implied that if work were done primarily or even partially as a contributor to the student's own educational program, employee status might be denied. This argument was firmly rejected by the British Columbia Labour Relations Board in a 1976 decision finding interns and residents to be employees. The Board found that the work was performed.

in a manner and within a format which provides a sustained clinical education..., [that] a high proportion of their actual daily work was of educational value to them, [that] the working and educational functions of the house staff in the hospital are largely overlapping and inseparable. Indeed, that is the raison d'etre of any program of clinical education. (CLRBR, 1976, 2, p. 161)

That is, the Board found a subordination of work to educational purposes far more powerful than is likely to be found in most T.A. situations. Nevertheless in the next sentence it stated, "But that fact is still no barrier to the legal coexistence of both employee and student status." 
Subsequent decisions by the Ontario, Saskatchewan and British Columbia labour relations boards took for granted the employee status of teaching assistants.

Other Canadian public policy. Many aspects of public policy other than the "employee" definition had the potential to affect T.A. unionization success. They, too, tended to be favourable in Canada. The relative success of T.A. unionization in Canada when compared to its virtual absence in the United States is the feature which invites a consideration of Canadian public policy in comparative terms.

Canadian public policy is more supportive of the union during the unionization drive. A much higher proportion of Canadian than of U.S. campaigns to secure certification are successful. ${ }^{5}$ This is attributable in large measure to Canadian law's kindlier treatment of such efforts (for example, a policy of determining a union's majority status on or close to the date of application for certification, rather than relying on a later electoral determination of majority support, as in the U.S.).

Thus T.A. unions, in common with other unions lacking massive power, benefit from sympathetic legal treatment of their unionization efforts. In addition, the high turnover of bargaining unit membership means that the speedier Canadian certification process reduces the otherwise formidable sign-up task.

The intermittent, non-continuous character of T.A. employment might have provided unsympathetic boards with an excuse to bar unionization. For example, the large majority of the electorate in the precedent-setting University of Toronto election were no longer employees on election date (which was set after the end of the regular school year). Another factor helpful to the union is the rule that only a majority of those voting rather than a majority of the unit is required to establish majority status.

Beyond the specifics of labour law and its labour board interpretation, "public policy" has a more general impact. In general, unionization in the Canadian public and quasi-public sector has been established longer, is more extensive, and receives more support from law and public opinion than is true in the U.S. (Feuille \& Anderson, 1980, p. 310; Gunderson, 1980, pp. 258, 259; Lewin \& Goldenberg, 1980, pp. 242, 246). The same is true of unionization of professional employees and other higher-status occupations. Related to both of these is a Canadian consensus that the unionization decision should be made by the public and quasi-public sector employee without employer influence or persuasion. This consensus may explain the relative mildness of the Canadian university administrators' response to T.A. unionization campaigns.

\section{Student Leadership Characteristics}

Although a variety of elements suggest a somewhat radical and activist leadership in organizing campaigns and the early phases of union activity, the 'T.A. collective bargaining' campuses do not appear to be those that during or prior to the unionization effort were Canada's most "activist" campuses. Toronto, clearly the birthplace of Canadian T.A. unionism, was relatively quiescent during the period 
of student activism of the late 1960's, nor was York mentioned among the more activist campuses. McGill, which was so mentioned, lacks T.A. collective bargaining. Simon Fraser, a leading activist campus, did not achieve certification until four years after Toronto and long after its unusual level of student activism had subsided (Quarter, 1972, pp. 61, 69, 78).

Graduate student associations. T.A. unions tended to emerge out of graduate student associations. This, for example, is true of the Canadian Union of Educational Workers (the former Graduate Assistants Association of the University of Toronto), which represents employees in six of the ten bargaining units. At two of the other four units (British Columbia and Simon Fraser) unionization also followed abortive efforts by the Association to negotiate improved employment conditions. It is hardly surprising that student activists should display a continu. ity of leadership.

Independent unions. Seven of the ten bargaining units were organized by independent unions not affiliated with the conventional labour movement. This absence of a direct labour linkage may have reflected simultaneously the somewhat different preferences of T.A. leadership and of potential unit members. T.A. leaders may have shared the usual leftist and intellectual ambivalence about conventional unions and may have preferred to retain their freedom of action unconstrained by "Gompersite" bureaucracies. Potential members may have had a more "rightist" objection to associating with the conventional labour movement and may have perceived a higher social status in an unaffiliated organization composed mainly of graduate students. The Canadian Union of Public Employees (a Canadian Labour Congress affiliate) represents three bargaining units. It may be 'the exception that proves the rule'; CUPE has an unusually high level of local autonomy in collective bargaining and political areas.

Difficult campaigns. The fact that the ultimately successful unionization campaigns frequently failed initially to secure sufficient employee support (resulting in withdrawn applications or lost representation votes), the fact that voter turnout at representation votes was low, the fact that the votes resulting in certification were won by modest majorities in most cases, and the fact that the unions did better where turnouts were lower, are all consistent with the image of significant perceptual differences between activists and at least a large sub-set of their potential constituents. Such facts are also consistent with the image of a committed and skillful minority achieving success despite a frequently uninterested majority and despite the hostility of a significant minority of T.A.s.

Radical demands. The initial demands of Canadian union negotiators included many that are consistent with (though not exclusive to) a radical student worldview. Examples include provisions covering students' political imprisonment, participation in university governance and departmental decision-making, auto. nomy and academic freedom in T.A. duties, protection against discrimination, retribution, and harassment for political, social, or sexual reasons. The large majority of these demands, however, did not make it into collective agreements, or were included in relatively innocuous form. This may suggest the difficulty 
union leadership had in convincing T.A.s that such non-economic issues were important enough to strike about.

The image of unionization so beloved of management is of a small group of 'troublemakers' stirring up otherwise 'happy and loyal' employees, using their superior commitment, organizational skills, and communication skills to manipulate consent. If we eliminate the moralizing oversimplification from this image we are left with something at least partially consistent with observed reality. Nevertheless, despite evidence of a somewhat radical orientation among student leaders we have no reason to believe that this was unique to the universities which unionized.

\section{Faculty Bargaining Characteristics}

It is plausible to suggest that the existence of faculty collective bargaining on a university campus could influence the emergence of T.A. bargaining. Faculty unions could be seen as role models or as competitors for limited tasks and scarce resources. Faculty unions or associations might wish to sponsor T.A. unionization, either for reasons of principle and solidarity or for reasons of control and co-optation. Faculty bargaining may silence or at least weaken objections that T.A. bargaining is illegitimate.

Despite this plausibility, faculty collective bargaining does not appear to have been a major influence on Canadian T.A. unionization. First, if faculty collective bargaining were a major influence one would expect T.A. bargaining to be most probable at those universities where faculty bargaining was most strongly entrenched. Canadian universities can be sorted into three groups of rising "strength of bargaining relationship": (a) no formal bargaining; (b) "Special Plan" bargaining (that is, bargaining outside the provincial labour relations statute); and (c) conventional collective bargaining (which differs from "Special Plan" bargaining in its possession of the right to strike and the right to invoke the protection of the labour relations statutes).

The Canadian Association of University Teachers (CAUT), which represents faculty at virtually all English-language universities, clearly regards "Special Plan" bargaining as weaker than conventional bargaining. A March 21, 1977 memorandum to affiliates urged "the utmost wariness" in responding to university offers to negotiate such relationships, in part because of problems of legal enforceability of terms contained therein.

Of the nine universities with T.A. bargaining only one is at a campus with 'no formal bargaining'. This mildly supports 'faculty bargaining' as cause, since such campuses represent about one-sixth of Canadian campuses. However, such a correlation could arise from causes other than faculty unionization's impact on T.A. unionization. For example, both groups may have independently moved toward bargaining because of concerns about adverse effects of budgetary cutbacks upon their own group. In addition, three of nine "bargaining" campuses have the weaker "Special Plan" format, a much higher proportion than the 'Special Plan' campuses are of all 'bargaining' campuses. Of about 55 Canadian 
universities outside Quebec, eight have "Special Plan" bargaining and thirty-six have conventional collective bargaining. Five of Quebec's seven universities have formal faculty bargaining, indeed within those five, unions represent thirteen faculty bargaining units.

Second, if faculty bargaining were a major influence, one would expect it to precede T.A. bargaining; causes normally precede effects. Yet on half the eight "faculty bargaining" campuses the T.A. union achieved certification before faculty achieved either certification or its informal "Special Plan" equivalent. Third, in no Canadian case did we find T.A. affiliation with or attempted affiliation with the faculty quasi-union, the CAUT. Fourth, we are familiar with no Canadian faculty bargaining unit that incorporates T.A.s within it (as is true on some U.S. campuses - for example, the City University of New York, and Rutgers University).

Fifth, faculty support for T.A. unionization appears to have been appreciably below the usual level of faculty support for student political activities. Impressionistic evidence suggests that faculty opinion was on balance quite hostile to the idea of T.A. collective bargaining. This is hardly surprising. Faculty members stand in a dual superior-subordinate relationship to T.A.s - as supervisors of their graduate academic performance and as supervisors of their T.A. work performance. Even more basically, the common T.A. union demand for an increased T.A. role in course content and teaching methods decisions (and a role legally enforceable, through the collective agreement, by binding arbitration) appear to have been widely perceived as threatening in both an objective and a subjective sense. Objectively the threat was to faculty power and control in and around the classroom. Subjectively, the threat was to a cherished ideology and symbolism that saw such power as "academic freedom", "professional autonomy", and "scholarly independence" - and therefore as central to the university's social mission.

Faculty bargaining characteristics seem not to differentiate between universities with and those without T.A. unions. This was true to an even greater extent at the time of T.A. unionization, a fact which suggests that the formalization of faculty bargaining and T.A. bargaining may be parallel trends in response to more general factors rather than either being a direct cause of or influence on the other.

\section{Sessional Instructors and Chargés de Cours}

Because the primary focus of this paper is the unionization of graduate students employed as teaching assistants, we will comment only briefly on the parallel movement to organize sessional instructors, who may be, but usually are not, graduate students. ("Sessional instructor" here refers to a person hired to teach a single course or more than one course on a course-by-course rate.). In only one case (Simon Fraser) is a substantial number of sessional instructors incorporated in the same bargaining unit as graduate teaching assistants. In that instance a much smaller proportion of sessional instructors than of teaching assistants was active in the organizing campaign. Their inclusion was at least in part the result of labour board acceptance of the university's anti-fragmentation argument with respect to bargaining unit definition. Ryerson Polytechnical Institute on the 
other hand has no graduate students and its sessional instructors followed hard on the heels of teaching assistants at Toronto and York in obtaining certification as a local of the Graduate Assistants' Association (GAA). Although they were not students at the institute which employed them many were (or had recently been) graduate students at Toronto or York. In their employment they had many of the same characteristics as teaching assistants: short-term, part-time, highturnover employment with minimal benefits and no security. York's non-graduate student Unit Two includes a substantial number of sessional instructors (course directors).

Graduate teaching assistants have not unionized in Québec, perhaps because of their relatively small numbers. A few graduate students are included among the chargés de cours (sessional instructors), who have. An apparently defensive concern about job opportunities, arising from the 1976 faculty strike at l'Université du Québec à Montréal, provided the initial stimulus to unionization. Their 1976 application for certification was rejected by the provincial Ministry of Labour but the Syndicat des Chargés de Cours de l'Université du Québec à Montréal (SCCUQ) was certified in 1978 to represent some 500 chargés de cours in that institution. In 1979 following a 54-day strike the administration applied for binding arbitration and a first contract was imposed. The major innovation was that hiring must be based on seniority (number of courses previously taught) although the administration retained the right to staff $10 \%$ of the courses at its own discretion. Subsequent negotiations have slightly increased benefits and more substantially increased the maximum number of courses which may be taught by a chargé de cours in an academic year. The membership (priority roster) now has approximately 1,000 names.

The unionization at UQAM occurred at a time when that university, experiencing both enrolment pressure and financial pressure, had increased greatly the proportion of its teaching done by chargés de cours. Nevertheless $62 \%$ of the chargés de cours indicated that their primary career lay outside the university, $55 \%$ were appointed only once and $69 \%$ were appointed only for a single course (Dionne, 1980, pp. 8-9). Although their signing of a "protocole d'harmonisation" with the faculty union is evidence of some community of interest, they have a competing interest, i.e., maintaining the proportion of teaching for which they are hired. The major motivation appears to be economic. Chargés de cours have been concerned with rates of pay, with total potential remuneration, with job security and with status. As a group of marginal employees they recognize their vulnerability in the face of fiscal retrenchment and their lack of protection against unilateral actions by their employers.

More recently the chargés de cours have unionized at the Université du Québec à Rimouski though negotiations for a first contract have not yet concluded. Applications are also pending at the remaining three campuses of the Université du Québec (Chicoutimi, Hull \& Trois Rivières). Chargés de cours at l'Université de Montréal have applied for certification; the University has opposed their application and the matter has been pending for several years. 


\section{IMPLICATIONS}

Our study suggests that one cannot predict the probability of a given university's future unionization merely by comparing its profile with that of the unionized universities. Several factors distinguish unionized campuses from those not unionized but the most potent determinants seem to be factors common to Canadian unjversities.

The unionized campuses were more likely to be in urban and/or pro-unionization locations, to have larger graduate student populations and to face greater budgetary concerns. They may also have been more administratively decentralized. A greater proportion of their graduate students were in the humanities and social sciences and were part-time students. The universities in which T.A.s initially unionized had lower graduate student incomes and a greater discrepancy between the incomes of humanities and social science students and those of others. These economic contributors to unionization did not characterize the universities in which T.A.s unionized later.

Characteristics the unionized universities shared with other Canadian universities appear to have been stronger influences on unionization. Predominant among them was the supportive legal treatment by Canadian labour relations boards. Making a more modest contribution were activist student leadership and faculty bargaining.

In passing we note that T.A. unionization is much more extensive in Canadian than in U.S. universities. None of the factors distinguishing unionized from nonunionized Canadian universities is less prominent in U.S. universities. In fact, in most instances those factors are probably stronger in many U.S. institutions. One exception may be faculty bargaining which although formalized in a smaller proportion of American universities is nevertheless vastly more extensive than T.A. bargaining. The major contrast between the U.S. and Canadian contexts, however, is in the extent to which public policy encourages and facilitates T.A. certification. This fact adds validity to the conclusion that the Canadian public policy context in which certification takes place is itself a major factor in the extent of T.A. certification.

Among public policy considerations the predominant influence was the position of Canadian labour relations boards that coverage by the labour relations statutes is not prevented either by the predominance of the student-to-teacher relationship over the employee-to-employer relationship, or by any unique features of the employer and its mission. Underlying this position may have been an implicit labour relations model that emphasized the commonalities rather than the differences across employer-employee relationships, and an implicit educational model that saw no serious negative impact of T.A. bargaining on graduate or undergraduate education.

\section{Triggering Events}

The effort to generate a profile of the university susceptible to T.A. unionization is likely to be unsuccessful not only because some major determinants are com- 
mon to most universities but also because each unionization experience was somewhat unique. The triggering events, the way the pro-unionization factors combined, how they were perceived by the actors (and especially which of them became salient in the perceptions and programs of the actors), and the talent, commitment, and orientation of the actors, all shaped a distinctive gestalt in each case.

For example, at Toronto the extraordinarily large number of combinations of T. A. duties and compensation appears to have been the salient factor. At McMaster, where support for graduate T.A.s was almost universal, observable differences in "topping up" between the experimental disciplines with access to substantial outside funding and the less affluent humanities and social science departments was central. At OISE, unusual uncertainty about the financial and organizational future of the institution, combined with the virtually complete unionization of other employee groups, appears to have posed graduate students' unionization as the only way to preserve their share of resources. At Regina the fortuitous presence of a small group of militant and capable student leaders appears to have been crucial. At British Columbia the unusually affluent position of T.A.s in one science department appears to have been important. At Simon Fraser, the mix of the fellowship and salary components in the total compensation was important.

\section{The Pre-Organizing Period}

Could one predict that those universities that "clean up their act" - i.e. make efforts to improve those substantive and procedural aspects of T.A. employment that have become the focus of past unionization campaigns - will be less likely to become unionized? Perhaps, but there are several caveats here.

First, several universities in the years before unionization made serious efforts to reform and regularize T.A. employment, using procedures involving consultation with graduate student representatives. These centralizing efforts appear to have foundered on the rock of departmental autonomy, with their main effect being to convince student leaders that consultative procedures could not solve T.A.s' problems.

Second, the unionized universities in our study did not, on balance, treat their T.A.s worse than did comparable non-unionized universities. Our study suggests that T.A. unionization was more a social-psychological phenomenon than an economic one, more an ideological demand for substantive equality than a pragmatic demand for as much money as the traffic would bear. It is clear that graduate T.A.s were more militant on the unionized campuses; it is not clear that the conditions they sought to change were worse than at other comparable universities. Thus, there may be no "act" to "clean up".

We cannot argue against institution-wide equity in the treatment of T.A.s, consultation in policy-development and administration, fair and consistent personnel administration or the provision of means for resolving grievances. Unfortunately; however, we cannot suggest that any or all of these will lessen significantly the probability of T.A. unionization. 


\section{The Organizing Period}

In retrospect, regardless of one's opinion of the wisdom of the Canadian boards' decisions, one can regret that a more searching analysis of their potential impact on the university's teaching function did not precede them. The boards did not appear to believe that there was sufficient uniqueness associated with employee, employer, work performed, or non-work relationships to require such an analysis. Although T.A. unions have been certified in three Canadian provinces, no university has as yet argued in a concerted fashion that the graduate student/advisor relationship must take precedence over the employee/employer relationship or that the very purpose of a university is compromised when the contractual regulation of the graduate T.A.'s secondary relationship with the university intrudes upon the primary relationship.

Such an argument might be presented in the context of the first application for certification in a new jurisd iction. Certainly a provincial labour relations board does not regard itself as bound by a ruling in a neighbouring province. For example, the Alberta Labour Relations Board in a 1980 decision chose not to follow the B.C. board's ruling that interns and residents are primarily employees. Instead it followed the (U.S.) NLRB's contrary finding (Rogow \& Birch, 1983, p. 66). If Canadian provinces can differ with respect to interns and residents, it is conceivable that a province can take a divergent position on T.A.s.

In determining strategy University administrators must consider the long-range as well as the short-range implications of the tactics adopted. For example, Canadian experience would suggest that management attempts to expand the definition of a bargaining unit in the hope of defeating a T.A. union's certification vote are unlikely to be successful and may result in a bargaining unit definition carrying within it the seeds of future problems. For example, Simon Fraser University espoused an anti-fragmentation argument in favour of a bargaining unit broader than that initially sought by the union and, while the vote was very close, the union obtained certification. Sessional Instructors, although they have little in common with T.A.s, are included, as are Language Instructors, who were unanimous in their demand for exclusion.

Of interest in the Carleton decision was the board's inclusion of R.A.s within the bargaining unit. The board's decision acknowledged the many different (including non-university) sources of funding for R.A.s, and implicitly recognized that the University was not the direct beneficiary of all of the research done. But for reasons not specified, neither of these findings kept it from including R.A.s in the T.A. unit. Perhaps the fact that the University had requested their inclusion influenced the decision. It is conceivable that the University was influenced by the hope that R.A.s would tip the representation vote against the union.

Even within the narrow constraints of permissible "employer behaviour" that Canadian labour laws permit, management responses could have been more vigorous than they were. (The comparative mildness of Canadian university management responses to certification campaigns explains why analysis earlier 
in this paper contains the implicit assumption that student desire for certification would be a good predictor of the probability of certification.)

It is easy to see why an employer would be hesitant about any activity which could be construed as illegal. Even innocent violations of the complex and limiting legislation can have serious repercussions. For example, McMaster's effort to provide information about the Union's by-laws (which proved to be unintentionally misleading as the document had been superseded by a later edition) resulted in the OLRB setting aside a failed representation vote and ordering a new vote which the Union won.

\section{SUMMARY}

Despite many unfavourable-to-unionization characteristics of employee groups, employers and work performed, teaching assistant unionism successfully established itself on nine Canadian campuses during the 1970s. Nevertheless, the relative weakness of $T$.A. unionism, the difficult unionization campaigns, the narrow electoral victories, and the evidence of large anti-bargaining groups among graduate students all suggest limited prospects for further unionization. This suggestion would be reinforced if university administrations were to do a more vigorous job (before and, to the limited extent permitted by Canadian law, during unionization campaigns) in communicating to graduate students and in providing them with trustable avenues for redress of grievances, and if anti-collective bargaining graduate students were to be less inept than they have been in mobilizing their supporters at the ballot box.

Offsetting these negative factors is the fact that T.A. bargaining is now an accepted institutional reality, with collective agreement achievements to point to, unions with dues income to support unionization drives, and the clear support of Canadian public policy.

Further, future budgetary crises, reorientations of university programs and priorities, and other shocks to the university system will periodically raise graduate student anxiety levels. The availability of established T.A. unions as a means of dealing with these anxieties should promote unionization. On balance, the probability of further unionization appears high.

\section{REFERENCES}

Alberta Board of Industrial Relations. The University Hospital Board and Board of Governors, The University of Alberta and the College of Physicians and Surgeons of Alberta and Professional Association of Interns and Residents of Alberta. October 15, 1980. Canadian Labour Relations Boards Reports, 1981, 3.

Bodner, G.A. The appropriateness of collective bargaining between educational institutions and their student/employees: A legal analysis. Special Report No. 32. Washington, D.C.: Academic Collective Bargaining Information Service, 1977.

Bognanno, M.F., \& Suntrup, E.L. Graduate assistants' response to unionization: The Minnesota experience. Labor Law Journal, 1976, 36. 
British Columbia Labour Relations Board. Annual Report, 1974 and following.

British Columbia Labour Relations Board. St. Paul's Hospital and Professional Association of Residents and Interns, No. 43/76, July 7, 1976. Canadian Labour Relations Boards Reports, 1976, 2.

Christenson, A. Collective bargaining in a university: The University of Wisconsin and the Teaching Assistants Association. University of Wisconsin Law Review, 1971.

Chronicle of Higher Education, April 7, 1980; May 22, 1980; August 25, 1980; January 19, 1981 ; February 23, 1981; April 13, 1981.

Council of Ontario Universities. Brief to the Ontario Council on University Affairs: A future of lost opportunities?, March 1981, 8-9, 10-11.

Council of Ontario Universities. Graduate student incomes in Ontario: 1972-73, April 1974: 1973.74, April 1975; 1974-75, August $1976 ; 1975.76$, May $1978 ; 1976.77$, May 1978; 1977-78, June $1979 ; 1978-79$; June 1980.

Dionne, M.P. La syndicalisation des chargés de cours: Evaluation et perspectives (The unionization of university lecturers: Evaluation and perspectives). Paper presented at the meeting of the Canadian Association of University Business Officers, Simon Fraser University, Burnaby, B.C., June 1980.

Étude de la validité de l'accreditation du syndicat des chargés de cours de l'Université du Québec a Montréal.

Feinsinger, N.P., \& Roe, E.J. The University of Wisconsin, Madison-campus - TAA dispute of 1969-70: A case study. University of Wisconsin Law Review, 1971.

Feuille, P., \& Anderson, J.C. Public sector bargaining: Policy and practice.Industrial Relations, Fall 1980, 19.

Fiorito, J., \& Greer, C.R. Determinants of U.S. unionism: Past research and future needs. Industrial Relations, Winter 1982, 21.

Forsyth, J.D. Collective bargaining with graduate student "employees": The University of Michigan experience. In T.N. Tice (Ed.). Campus employment relations. Ann Arbor: Institute of Continuing Legal Education, 1976.

Gunderson, M. Public sector compensation in Canada and the U.S. Industrial Relations, Fall $1980,19$.

Lewin, D., \& Goldenberg, S.B. Public sector unionism in the U.S. and Canada. Industrial Relations, Fall 1980, 19.

Lipset, S.M. The new class and the professoriate. In Bruce-Biggs (Ed.), The new class. New York: McGraw-Hill, 1979.

Ontario Labour Relations Board. Annual reports, 1973-74 through 1976-77, 1980-81.

Ontario Labour Relations Board. Graduate Assistants' Association [applicant] and Carleton University [respondent] and Carleton University Support Staff Association [intervenor]. In Ontario Labour Relations Board Reports, File number 1826-76-R, February 8, 1978.

Ontario Labour Relations Board. Graduate Assistants' Association and Victoria University, June 6, 1974.

Ontario. Labour Relations Board. Graduate Assistants' Association and York University. Canadian Labour Relations Boards Reports, 1976, 1 .

Ontario Labour Relations Board. Canadian Union of Educational Workers and York University. Ontario Labour Relations Board Reports, May 1981.

Ontario Ministry of Colleges and Universities. Background data: Preliminary report of the future role of the universities in Ontario, March 1981.

Quarter, J. The student movement of the 60 's. Ontario Institute for the Study of Education, 1972. 
Rogow, R., \& Birch, D.R. The emergence of teaching assistant bargaining in Canada: Faculty of Business Administration discussion paper 83-01-03. Burnaby: Simon Fraser University, 1983.

Saskatchewan Labour Relations Board. Canadian Union of Public Employees and the University of Regina. LRB File No. 030-78, April 18, 1978.

Sherman, F.E., \& Loeffler, D. Universities, unions, and the rule of law: The teaching assistants at Wisconsin. University of Wisconsin Law Review, 1971.

\section{FOOTNOTES}

${ }^{1}$ The authors were, respectively, a member of and the chairman of the Simon Fraser University management negotiating committee in the first round of negotiations for a teaching assistant collective agreement. Interviews and other communications with management industrial relations representatives of almost all the unionized Canadian universities (and, to a lesser extent, with union representatives) provide the basis for most of the statements not otherwise footnoted.

${ }^{2}$ Further substantive detail, methodological information and citations are available in the authors' monograph, "The Emergence of Teaching Assistant Bargaining", Discussion Paper 83-01-03, Faculty of Business Administration, Simon Fraser University.

${ }^{3}$ A non-trivial question existed in the case of research assistants (R.A.'s), however, regarding whose employees they were - that is, whether the university or the faculty grant holder was the employer. A Saskatchewan court ruling included within the T.A. Union at Regina all R.A.'s, including those on externally funded research grants.

${ }^{4}$ Based on what it argued was a change in OLRB policy in the Carleton certification decision (see below) the Canadian Union of Educational Workers re-applied for a 300-person group of "graduate assistants and research assistants paid from [university] operating funds" at York. The Board, finding that the work of such assistants (as in 1975) was largely spurious and "devised as a means of dispensing money" held them to be non-employees and therefore rejected the union application (OLRB Reports, May 1981, pp. 601-604).

${ }^{5}$ About two-thirds of Ontario certification applications and about nine-tenths of British Columbia certification applications are successful. The comparable U.S. figure is under one-half. See OLRB Reports, Annual Reports of Ontario Ministry of Labour, and Annual Reports of BCLRB. 